\title{
Combined X-Ray Diffraction and Absorption Study of Crystalline Vanadium-Doped Lithium Disilicate
}

\author{
W. PAszkowicz ${ }^{a, *}$, A. Wolska ${ }^{a}$, M.T. KlepkA ${ }^{a}$, S. ABD El All ${ }^{b}$ \\ AND F.M. EZZ-ELDIN ${ }^{b}$ \\ ${ }^{a}$ Institute of Physics, Polish Academy of Sciences, al. Lotników 32/46, 02-668 Warszawa, Poland \\ ${ }^{b}$ Center of Research and Radiation Technology, Nasr City, Cairo 0002, Egypt

\begin{abstract}
Structure of vanadium-doped lithium disilicate, $\mathrm{Li}_{2} \mathrm{Si}_{2} \mathrm{O}_{5}$ (Ccc2 space group) is studied. This crystalline phase is obtained by annealing of the doped lithium disilicate glass for $4 \mathrm{~h}$ at $550{ }^{\circ} \mathrm{C}$. X-ray diffraction and X-ray absorption near-edge structure analysis indicate location of vanadium atoms at Si sites. the lattice parameters are found to increase isotropically with increasing vanadium content. the valency of vanadium ions is discussed on the basis of X-ray absorption near-edge structure results.
\end{abstract}

PACS numbers: 61.43.Fs, 61.66.Fn, 71.20.Ps, 81.05.Je

\section{Introduction}

Lithium-silicon oxides, both amorphous and crystalline, exhibit interesting physicochemical (electrical and mechanical) properties which may lead to their wider applications. They can be prepared by various methods [1]. Their properties depend, in particular, on the presence of short-range or long-range order. Lithium-based conducting glasses are promising candidates for electrolyte materials of thin-film batteries due to their isotropic ionic conductivity. However, at room temperature most of such conducting glasses exhibit relatively low ionic conductivity values, in the range $10^{-7}$ to $10^{-8} \mathrm{~S} / \mathrm{m}$. In order to increase the conductivity, some specific additives have been used, one of them being vanadium. In a recent work on borate glasses, vanadium dopant at a level of several percent was used for this purpose [2-4]; annealing of these materials resulted in modification of physical properties [2].

It is noteworthy that nucleation and crystallisation of ordered phases are frequently favoured if an additive is used, and they may lead to unwanted features of the materials, therefore studies on glass annealing are of high importance. Nucleation and crystallisation of ordered phases in lithium disilicate glass has been studied for several decades, see e.g. Refs. [5-16]. The reported studies concern, in particular, crystalline $\mathrm{Li}_{2} \mathrm{Si}_{2} \mathrm{O}_{5}$ compound and $\mathrm{Li}_{2} \mathrm{Si}_{2} \mathrm{O}_{5}$ based glasses exhibiting good mechanical properties and applicable e.g. in dentistry as a high-strength machinable glass ceramic $[17,18]$ and as substrates in storage media [19]. As concerns the mechanical

* corresponding author; e-mail: paszk@ifpan.edu.pl properties, the presence of $\mathrm{Li}_{2} \mathrm{Si}_{2} \mathrm{O}_{5}$ crystals in the glass matrix enhances the strength of the glass [20]. Other potential applications involve the ozone detection [21].

The interest in modification of $\mathrm{Li}_{2} \mathrm{Si}_{2} \mathrm{O}_{5}$ properties by a third component gave motivation to structural studies of crystalline $\mathrm{Li}_{2} \mathrm{Si}_{2} \mathrm{O}_{5}$ and $\mathrm{Li}_{2} \mathrm{Si}_{2} \mathrm{O}_{5}$ doped, e.g., with aluminium [22], boron [23], or phosphorus [24]. Another possible dopant is vanadium, for which, up to our knowledge, crystallisation has not been studied yet. Only the glass formation and nucleation phenomena have been studied for samples jointly doped with vanadium and other $5 \mathrm{~A} / 5 \mathrm{~B}$ elements [25].

\section{Experimental}

\subsection{Crystallisation process}

At the first step, the glass of composition $\left(\mathrm{Li}_{2} \mathrm{Si}_{2} \mathrm{O}_{5}\right)_{1-u}\left(\mathrm{~V}_{2} \mathrm{O}_{5}\right)_{u}$ with $u$ ranging from 0.005 to 0.06 was prepared by heating a mixture of quartz $\left(\mathrm{SiO}_{2}\right)$, lithium carbonate $\left(\mathrm{Li}_{2} \mathrm{CO}_{3}\right)$ and vanadium pentoxide $\left(\mathrm{V}_{2} \mathrm{O}_{5}\right)$ at $1400^{\circ} \mathrm{C}$ for $3 \mathrm{~h}$ and then cooled. The melting process was carried out in platinum crucibles and during the melting the crucibles were covered by a platinum lids to minimize any volatilization process. Therefore, no weight loss analyses were carried out. The crystalline $\mathrm{Li}_{2} \mathrm{Si}_{2} \mathrm{O}_{5}$-based phase was then prepared by annealing of the glass for four hours at $550^{\circ} \mathrm{C}$, i.e. slightly above the nucleation temperature of $\approx 500{ }^{\circ} \mathrm{C}$ (see e.g. Ref. [16]).

\subsection{Characterisation techniques}

X-ray diffraction (XRD) experiments were performed employing a modern X-Pert MPD diffractometer equipped with a Johansson monochromator and a strip 
detector. The Rietveld refinements were performed using the FullProf program [26]. For profile shape the pseudo-Voigt function was employed. The X-ray absorption experiment was conducted at the CEMO beamline (Hasylab at DESY, Hamburg). The X-ray absorption near edge structure (XANES) measurements were carried out at room temperature using a seven-element silicon fluorescence detector.

\section{Results and discussion}

The crystallographic information on $\mathrm{Li}_{2} \mathrm{Si}_{2} \mathrm{O}_{5}$, one of several compounds existing (as noted in Refs. [27, 28] in the $\mathrm{Li}_{2} \mathrm{O}-\mathrm{SiO}_{2}$ system) is scarce. This compound crystallises in $C c c 2$ space group (stable form [29]) or a metastable Pbcn form [30, 31]. However, most papers refer to a monoclinic cell $[9,32-36]$ which has been used even recently $[9,36]$ despite noticing [35] a discrepancy in diffraction-peak intensities between experiment and calculation. The monoclinic cell has a different symmetry but the same size as the $C c c 2$ stable form $\left(\beta=90^{\circ}\right)$, so it is still qualitatively useful in comparisons (see Table). Crystallographic and electronic structure of this material have also been studied theoretically in Ref. [37] assuming the monoclinic cell and in Refs. [38-40] assuming the orthorhombic cell.

TABLE

Unit cell of lithium disilicate doped with vanadium, $\mathrm{Li}_{2}\left(\mathrm{Si}_{1-t} \mathrm{~V}_{t}\right)_{2} \mathrm{O}_{5}$. For vanadium-free case, the values extrapolated from lattice parameters of samples A-D, and literature data on the structure (orthorhombic $C c c 2$ or monoclinic $C 1 c 1^{a}$ ) are included (the data referring to the monoclinic cell are given in italics).

\begin{tabular}{|c|c|c|c|c|c|c|c|c|c|c|}
\hline$t$ & $a[\AA]$ & $b[\AA]$ & $c[\AA]$ & $\beta\left[{ }^{\circ}\right]$ & $V\left[\AA^{3}\right]$ & $T[\mathrm{~K}]$ & $\begin{array}{c}\text { System/ } \\
\text { space group }\end{array}$ & Study & Ref./sample & Year \\
\hline 0 & 5.82 & 14.66 & 4.79 & 90.08 & 408.7 & $\mathrm{RT}$ & monoclinic $C 1 c 1^{a}$ & $\exp$ & {$[32]$} & 1961 \\
\hline 0 & 5.813 & 14.635 & 4.783 & 90 & 406.91 & $\mathrm{RT}$ & monoclinic $C 1 c 1^{a}$ & $\exp$ & {$[34]$} & 1995 \\
\hline 0 & $5.823(3)$ & $14.665(6)$ & $4.775(2)$ & 90 & 407.76 & $\mathrm{RT}$ & monoclinic $C 1 c 1^{a}$ & $\exp$ & {$[35]$} & 1996 \\
\hline 0 & 5.7 & 15.1 & 4.7 & 90 & 404.5 & RT & monoclinic $C 1 c 1^{a}$ & $\exp$ & {$[9]$} & 1997 \\
\hline 0 & $5.807(2)$ & $14.582(7)$ & $4.773(3)$ & 90 & $404.2(3)$ & 293 & orthorhombic $C c c 2$ & $\exp$ & {$[29]$} & 1998 \\
\hline 0 & $5.826(9)$ & $14.632(11)$ & $4.799(4)$ & $90.20(13)$ & 409.1(1.2) & $\mathrm{RT}$ & monoclinic $C 1 c 1^{a}$ & $\exp$ & {$[36]$} & 2000 \\
\hline 0 & 5.97 & 14.75 & 4.94 & 90 & 435.0 & - & orthorhombic $C c c 2$ & calc & {$[38]$} & 2005 \\
\hline 0 & 5.6830 & 14.6480 & 4.7840 & 90 & 398.242 & - & orthorhombic $C c c 2$ & calc & {$[40]$} & 2006 \\
\hline 0 & 5.8235 & 14.612 & 4.7815 & 90 & 406.9 & $300(3)$ & orthorhombic $C c c 2$ & $\exp$ & $\begin{array}{l}\text { this work } \\
\text { (extrapolation) }\end{array}$ & 2010 \\
\hline 0.004 & $5.8237(2)$ & $14.6225(4)$ & $4.7835(2)$ & 90 & 407.35 & $300(3)$ & orthorhombic $C c c 2$ & $\exp$ & $\begin{array}{l}\text { sample A, } \\
\text { this work }\end{array}$ & 2010 \\
\hline 0.016 & $5.8292(1)$ & $14.6114(5)$ & $4.7876(1)$ & 90 & 407.77 & $300(3)$ & orthorhombic $C c c 2$ & $\exp$ & $\begin{array}{l}\text { sample B, } \\
\text { this work }\end{array}$ & 2010 \\
\hline 0.033 & $5.8333(4)$ & $14.624(1)$ & $4.7956(4)$ & 90 & 409.09 & $300(3)$ & orthorhombic $C c c 2$ & $\exp$ & $\begin{array}{l}\text { sample C, } \\
\text { this work }\end{array}$ & 2010 \\
\hline 0.046 & $5.8360(2)$ & $14.6401(6)$ & $4.7996(2)$ & 90 & 410.06 & $300(3)$ & orthorhombic $C c c 2$ & $\exp$ & $\begin{array}{l}\text { sample D, } \\
\text { this work }\end{array}$ & 2010 \\
\hline
\end{tabular}

$a$ The true symmetry is orthorhombic, see text.

The present synthesis procedure gave virtually pure $\mathrm{Li}_{2} \mathrm{Si}_{2} \mathrm{O}_{5}$ phase of orthorhombic $C c c 2$ space group [29] with vanadium present in the lattice, as indicated by increase of lattice parameters with rising vanadium content. Samples A and B crystallized completely. In the samples $\mathrm{C}$ and $\mathrm{D}$ a very small addition of an amorphous phase was observed. Control samples annealed in a shorter time were multiphase, indicating that the given crystallisation process of $\mathrm{Li}_{2} \mathrm{Si}_{2} \mathrm{O}_{5}$ requires at least about $4 \mathrm{~h}$, if the annealing temperature of $550^{\circ} \mathrm{C}$ is used. The presence of the tiny amount of amorphous phase in the samples richer in vanadium suggests that the crystallisation process time should be slightly longer than $4 \mathrm{~h}$ for samples rich in vanadium. The crystallisation of vana- dium doped $\mathrm{Li}_{2} \mathrm{Si}_{2} \mathrm{O}_{5}$ glass shows some similarities with that for compositionally and structurally related phosphate glasses studied in Ref. [24].

The Rietveld refinements were performed assuming the $C c c 2$ space group assuming a partial substitution of $\mathrm{Si}^{4+}$ by $\mathrm{V}^{4+}$ ions (see the example in Fig. 1). A satisfactory correction for preferred orientation was obtained assuming the March-Dollase function and [001] orientation direction (this direction has been also found to be the crystallite orientation at the surface of $\mathrm{Li}_{2} \mathrm{Si}_{2} \mathrm{O}_{5}$ ceramics $[34,10])$. The refinements of data collected for doped samples show that lattice parameters $a, b$, and $c$ vary isotropically with increasing vanadium content, as shown in Fig. 2 and quoted in Table. For vanadium free case, 
the present extrapolated lattice parameters are higher, by about $0.2 \%$, than the values of Ref. [29]. A possible cause is some difference in preparation way of the studied materials. The older data assuming the monoclinic (pseudo-orthorhombic) cell exhibit a rather large scatter of the unit cell size.

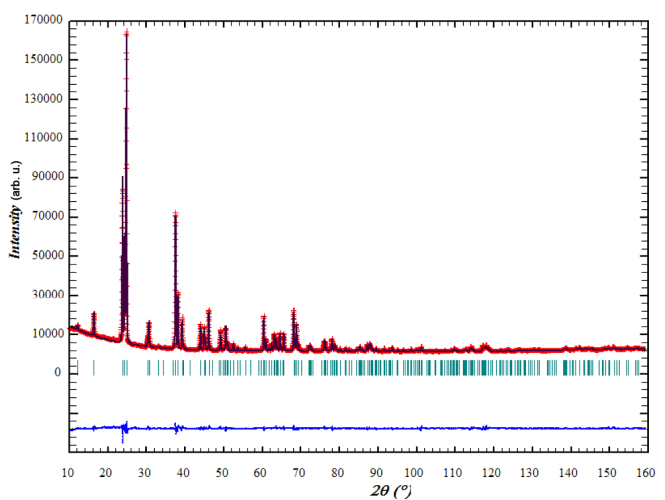

Fig. 1. Example of the Rietveld refinement for the sample B. The experimental points are denoted by crosses, the calculated profile - by a solid line. Vertical bars represent the reflection positions. The difference curve is shown below the pattern.
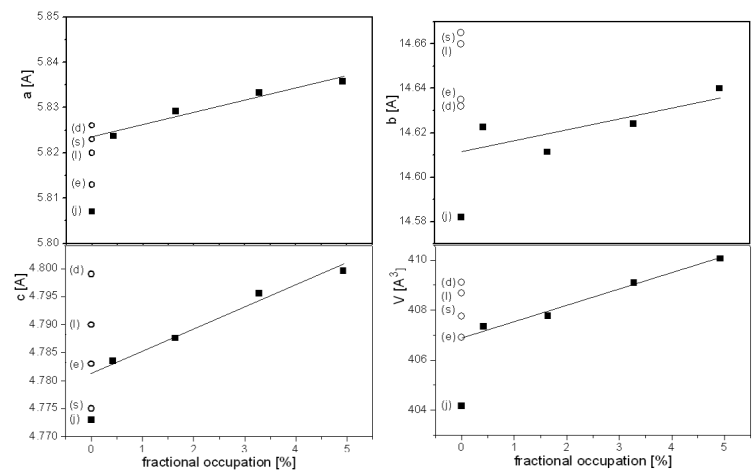

Fig. 2. Variation of cell parameters with increasing vanadium content in $\mathrm{Li}_{2}\left(\mathrm{Si}_{1-t} \mathrm{~V}_{t}\right)_{2} \mathrm{O}_{5}$ (filled squares); the literature data for vanadium-free samples refer to [29] (j). Data for $\mathrm{Li}_{2} \mathrm{Si}_{2} \mathrm{O}_{5}$ reported as monoclinic in Refs. [32, 34-36] (open circles) are denoted by (l), (e), (s) and (d), respectively.

X-ray absorption techniques provide, in a selective way, information about the first and further neighbours of the given element atoms remaining in an ordered or in a disordered state. They are also very helpful in determination of the valence state. In order to confirm the finding of the XRD that vanadium substitutes silicon atoms in the lithium disilicate unit cell, i.e. that the formula can be written as $\mathrm{Li}_{2}\left(\mathrm{Si}_{1-t} \mathrm{~V}_{t}\right)_{2} \mathrm{O}_{5}$, X-ray absorption measurements were undertaken.

Normalized XANES spectra at the vanadium $K$ edge are presented in Fig. 3a. The shapes of the spectra are very similar, with only slight changes between lower (samples $\mathrm{A}$ and $\mathrm{B}$ ) and higher (samples $\mathrm{C}$ and $\mathrm{D}$ ) vanadium concentration. However, in all cases, a very pronounced pre-peak is observed. According to Ref. [41], the pre-peak position and intensity depend strongly on the vanadium oxidation state and symmetry. The authors of the cited paper have checked several standard compounds and constructed the figures, where the oxidation state was compared with the measured position of the energy edge and pre-peak intensity for normalized spectrum. Both of these values: position $\left(E_{1 / 2} \approx 15 \mathrm{eV}\right)$ and intensity of the pre-peak $(\approx 0.7)$ found for the investigated samples indicate that vanadium ionicity is equal to $+4,+5$ or intermediate. This supports the hypothesis that vanadium dopant substitutes silicon atoms. Due to the charge balance, the expected valency of vanadium located at $\mathrm{Si}$ sites is +4 , being in line with the above observations based on pre-peak intensity. The presence of vanadium at a higher valence state is not completely excluded, it would be accompanied by vacancies at the $\mathrm{Si}$ site. In order to check how the possible vanadium location in vanadium-doped $\mathrm{Li}_{2} \mathrm{Si}_{2} \mathrm{O}_{5}$ compound influences the shape of the XANES spectra, ab initio calculations using FEFF 8.4 [42] were carried out. A cluster of $10 \AA$ in radius was first created using the known crystallographic data. Then, the vanadium atom was introduced substituting either $\mathrm{Si}\left(\mathrm{V}_{\mathrm{Si}}\right)$ or $\mathrm{Li}\left(\mathrm{V}_{\mathrm{Li}}\right)$ and for both these models the spectra were calculated. The results are shown in Fig. 3b. Comparison with the experimental spectrum indicates that $\mathrm{V}$ atoms prefer the Si sites.

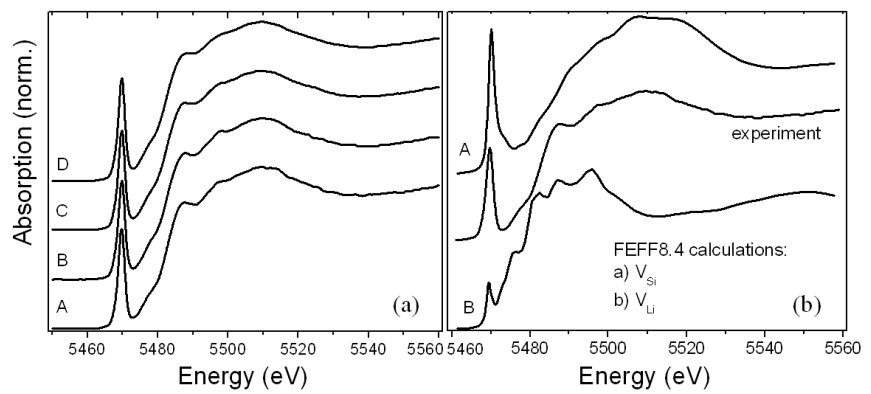

Fig. 3. Result of absorption measurement: normalized spectra for samples A-D (for clarity, the curves are shifted by a constant value) (a); comparison of experiment with FEFF modelling results assuming vanadium substitution at $\mathrm{Si}$ or at Li site for sample A (b).

In summary, the structural changes in vanadium-doped $\mathrm{Li}_{2} \mathrm{Si}_{2} \mathrm{O}_{5}$ compound caused by vanadium doping were experimentally studied by X-ray diffraction and absorption methods. The obtained results indicate clearly that the chemical formula of the crystallised material is $\mathrm{Li}_{2}(\mathrm{Si}, \mathrm{V})_{2} \mathrm{O}_{5}$.

The doping is found to cause isotropic lattice expansion. 


\section{Acknowledgments}

The research leading to these results has received funding from the European Community Seventh Framework Programme (FP7/2007-2013) under grant agreement no. 226716.

\section{References}

[1] H. Pfeiffer, P. Bosch, S. Bulbulian, J. Nucl. Mater. 257, 309 (1998).

[2] N.A. El-Alaily, R.M. Mohamed, Nucl. Instrum. Methods Phys. Res. B 179, 230 (2001).

[3] Y.-I. Lee, J.-H. Lee, S.-H. Hong, Y. Park, Solid State Ionics 175, 687 (2004)

[4] S.Y. Marzouk, N.A. Elalaily, F.M. Ezz-Eldin, W.M. Abd-Allah, Physica B 382, 340 (2006).

[5] G.E. Rindome, J. Am. Ceram. Soc. 45, 7 (1962).

[6] T. Furukawa, W.B. White, Phys. Chem. Glasses 20, 69 (1979)

[7] M.F. Barker, T.-H. Wang, P.F. James, Phys. Chem. Glasses 29, 240 (1988).

[8] J. Deubener, R. Brückner, M. Sternitzke, J. Non-Cryst. Solids 163, 1 (1993).

[9] E.D. Zanotto, J. Non-Cryst. Solids 219, 42 (1997).

[10] Y. Ding, Y. Miura, H. Yamaji, Phys. Chem. Glasses - Eur. J. Glass Sci. Technol. Part B 39, 338 (1998).

[11] Y. Iqbal, W.E. Lee, D. Holland, P.F. James, J. Non-Cryst. Solids 224, 1 (1998).

[12] L. Hasdemir, R. Brückner, J. Deubener, Phys. Chem. Glasses - Eur. J. Glass Sci. Technol. B 39, 253 (1998).

[13] L.L. Burgner, P. Lucas, M.C. Weinberg, P.C. Soares Jr., E.D. Zanotto, J. Non-Cryst. Solids 274, 188 (2000).

[14] P.C. Soares, Jr., E.D. Zanotto, V.M. Fokin, H. Jain, J. Non-Cryst. Solids 331, 217 (2003).

[15] V.M. Fokin, E.D. Zanotto, J.W.P. Schmelzer, O.V. Potapov, J. Non-Cryst. Solids 351, 1491 (2005).

[16] W. Höland, E. Apel, Ch. van 't Hoen, V. Rheinberger, J. Non-Cryst. Solids 352, 4041 (2006).

[17] W. Höland, V. Rheinberger, E. Apel, C. van't Hoen, J. Eur. Ceram. Soc. 27, 1521 (2007).

[18] Lithium silicate glass ceramic, US Patent 7452836 (2008).

[19] Composition inorganique pour un support d'enregistrement d'informations, European Patent EP1772440 (2007).

[20] M.P. Borom, A.M. Turkalo, R.H. Doremus, J. Am. Ceram. Soc. 58, 385 (1975)
[21] K. Ben Saad, H. Hamzaoui, A. Labidi, B. Bessaïs, Appl. Surf. Sci. 254, 3955 (2008).

[22] M. Nocun, M. Handke, J. Molec. Struct. 596, 139 (2001).

[23] T. Furukawa, W.B. White, Phys. Chem. Glasses 21, 85 (1979).

[24] Y. Iqbal, W.E. Lee, D. Holland, P.F. James, J. Mater. Sci. 34, 4399 (1999).

[25] M.E. Schlesinger, Ph.D. Thesis, Arizona Univ., Tucson, AZ 1988.

[26] J. Rodríguez-Carvajal, Physica B, Phys. Condens. Matter. 192, 55 (1993)

[27] A. Romero-Serrano, C. Gomez-Yańez, M. Hallen-Lopez, J. Araujo-Osorio, J. Am. Ceram. Soc. $\mathbf{8 8}$ 141 (2005).

[28] H. Krüger, Ph.D. Thesis, Leopold-Franzens-Universität Innsbruck, 2007.

[29] B.H.W.S. de Jong, H.T.J. Supér, A.L. Spek, N. Veldman, G. Nachtegaal, J.C. Fischer, Acta Crystallogr. B 54, 568 (1998).

[30] R.I. Smith, R.A. Howie, A.R. West, A. Aragón-Pińa, M.E. Villafuerte-Castrejón, Acta Crystallogr. C $\mathbf{4 6}$, 363 (1990).

[31] R.I. Smith, A.R. West, I. Abrahams, P.G. Bruce, Powd. Diffract. 5, 137 (1990).

[32] F. Liebau, Acta Crystallogr. 14, 389 (1961).

[33] G.E. Rindome, J. Am. Ceram. Soc. 45, 7 (1962).

[34] K. Engel, G.H. Frischat, Textures Microstruct. 24 , 155 (1995).

[35] D.B. Sullenger, J.S. Cantrell, T.A. Beiter, D.W. Tomlin, Mound Laboratory, Monsanto Chemical Co., (Miamisburg, Ohio) 1996.

[36] J. Deubener, J. Non-Cryst. Solids 274, 195 (2000).

[37] Computational Modeling of Materials and Processing, Ceramic Transactions, Vol. 69, Eds. J.H. Simmons, E.R. Fuller Jr., A.L. Dragoo, E.J. Garboezi, American Ceramic Society, Westerville, OH 1997.

[38] Z. Du, N.H. de Leeuw, J. Mater. Chem. 15, 4167 (2005).

[39] J. Du, L.R. Corrales, Phys. Chem. B 110, 22346 (2006).

[40] A. Pedone, G. Malavasi, M.C. Menziani, A.N. Cormack, U. Segre, J. Phys. Chem. B 110, 11780 (2006).

[41] P. Chaurand, J. Rose, V. Briois, M. Salome, O. Proux, V. Nassif, L. Olivi, J. Susini, J.-L. Hazemann, J.-Y. Bottero, J. Phys. Chem. B 111, 5101 (2007).

[42] A.L. Ankudinov, B. Ravel, J.J. Rehr, S.D. Conradson, Phys. Rev. B 58, 7565 (1998). 